\title{
Some Evidence On The Secondary Market Trading Of Syndicated Loans
}

Peter J. Nigro, Bryant University, USA

Jonathan D. Jones, Office of Thrift Supervision, Washington, USA

Murat Aydogdu, Rhode Island College, USA

\begin{abstract}
An important recent development in U.S. capital markets is the tremendous growth in the secondary market trading of syndicated loans. This paper uses a unique trading data set for syndicated loans over the period 1997 to 2003 to empirically investigate two major issues. First, we present a statistical overview of the recent growth in the secondary market trading of syndicated loans. Second, we examine the determinants of which syndicated loans are most likely to be traded in the secondary market using binomial logistic regression models. We find that syndicated loans that are larger, have longer maturities, are underwritten by larger syndicates, and are used for debt repayment, takeovers, and leveraged buyouts are more likely to be traded. Lender reputation plays an important role as well, with loans originated by very active lenders more likely to be traded. We also find that syndicated loans made to borrowers with only senior debt ratings are more likely to be traded in the secondary market than loans made to borrowers with both a debt rating and equity that trades in a stock exchange. This result most likely reflects the growing demand of institutional investors for the higher yields of levered and highly levered syndicated loans made to riskier opaque borrowers with less available market information.
\end{abstract}

Keywords: Syndicated Loans, Secondary Market Trading

\section{INTRODUCTION}

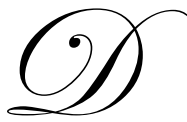

uring the past decade, syndicated loans have increasingly become the financing choice of large- and mid-sized U.S. corporate borrowers. According to recent data released by federal banking regulators, syndicated loan originations in the primary market were $\$ 1.2$ trillion in 2004, compared to only $\$ 37$ million in 1987 (Kulikowski 2004). Despite the growing importance of syndicated lending and the emergence of syndicated loans as an important asset class in capital markets, academic research on the role of syndicated lending in the capital markets has been limited. ${ }^{1}$ Part of the reason for the lack of research on syndicated lending is that until very recently, in sharp contrast to equities and bonds, syndicated loans were not actively traded in the secondary market.

Since 1995, however, a rapidly expanding secondary market has developed for trading syndicated loans. According to Loan Pricing Corporation (LPC) data, secondary market volume for syndicated loans was $\$ 145$ billion in 2003, compared to $\$ 9$ billion in 1991, representing a rate of growth of over 27 percent annually. This tremendous growth in the secondary market trading of syndicated loans reflects in large part a shift from traditional relationshipbased loans made by banks to a more efficient, investor-driven syndicated loan market. Institutional investors have been drawn to the syndicated loan market by the higher returns and lower price volatility associated with traded syndicated loans. Today, the syndicated loan market is the largest capital market in the United States (Okel 2005).

As the presence of institutional investors has grown in the market for syndicated loans, their familiarity with the information that is available in public bond markets has led them to demand both more information and standardized credit risk assessment for syndicated loans as well. Indeed, the presence of institutional investors has

\footnotetext{
${ }^{1}$ See, for example, Simons (1993), Dennis and Mullineaux (2000), Lee and Mullineaux (2004), and Jones, Lang, and Nigro (2005).
} 
been the catalyst for increased efficiencies in the syndicated loan market. These greater efficiencies are the result of a proliferation of available market information, such as syndicated loan indexes, loan ratings and research, credit risk models and data from third-party firms, such as Standard \& Poor's, Loan Pricing Corporation, Securities Data Corporation, and Moody's/KMV.

These changes have made information much more widely available on syndicated loans, transforming the historically opaque syndicated loan market into a much more transparent market. Banks, which historically have played both an intermediary and investor role, are finding that these roles have become much more distinct in today's capital markets. For example, the traditional club lending by larger agent banks that have specialized credit knowledge of corporate borrowers is rapidly being replaced by syndicated lending arrangements that involve different types of nonbank investors, such as pension companies, hedge funds, insurance companies, and mutual funds. As an illustration of the participation by a wider variety of investors, during the first four months of 2005, both bank and nonbank investors have already placed $\$ 4$ billion in bank loan funds, representing nearly a tenfold increase from 2004 (Opdyke 2005). This surge in demand has been driven largely by the flexibility of the contract terms for syndicated loans, the higher yields on these loans, and the current interest rate environment. ${ }^{2}$

Today's new breed of lenders uses portfolio theory and the secondary market trading of syndicated loans to manage the credit risk of their loan portfolios. Oliver, Wyman \& Company (1999) estimate that the potential benefits from portfolio diversification are on the order of 25 percent of economic capital for a typical multinational bank. As such, these new lenders are rapidly replacing the traditional buy-and-hold bank lenders of the past. The relationship pricing of loans by agent banks has been largely replaced by competitive pricing. This has occurred largely because of the widespread availability of comparative syndicated loan pricing today.

The development of an efficient, liquid, and transparent syndicated loan market continues its rapid pace. Syndicated loans originated in the primary market allow for a more efficient geographical and institutional sharing of risk among lenders. As noted by Yago and McCarthy (2004), the primary syndicated loan market provides borrowers with an alternative to high yield bonds and illiquid bilateral commercial loans as funding sources. The primary market also provides an important source of credit to lower-rated companies.

On the other hand, the trading of syndicated loans in a liquid and transparent secondary market provides lenders with the opportunity to actively manage the credit risk in their loan portfolios. For example, during economic downturns, lenders are able to sell portions of their riskier syndicated credits to others who are willing to assume the credit risk. Also, the secondary market prices of syndicated loans are able to adjust quickly to reflect changes in credit quality and market conditions. As such, a key empirical issue is to identify the borrower, lender, and loan characteristics that account for the rapid development and growth in the secondary market trading of syndicated loans.

This paper uses Loan Pricing Corporation data for approximately 39,000 syndicated loans originated in the primary market over the period 1997 to 2003 to empirically examine factors that have played a role in the rapidly expanding secondary market for syndicated loans. Our empirical work documents several interesting stylized facts. First, syndicated loans that are larger, have longer maturities, and are underwritten by larger syndicates are more likely to be traded in the secondary market.

Second, information about the borrower also plays an important role in whether a loan is traded. We find that loans made to borrowers with senior debt ratings are more likely to be traded, while loans made to borrowers with publicly traded equity are less likely to trade in the secondary market. This result suggests that the dramatic increase in information that has characterized the syndicated loan market recently has had a greater impact on borrowers that only have public debt ratings. In contrast, loans made to borrowers with equity already trading, and therefore a greater amount of market information, are actually less likely to be traded in the secondary market. This most likely reflects the fact that borrowers whose equity trades are probably less risky, and therefore have lower yields on their traded loans than would be the case for loans made to borrowers whose equity does not trade.

\footnotetext{
${ }^{2}$ Syndicated loans are typically variable-rate instruments, the use of which greatly reduces interest rate risk in a rising rate environment.
} 
Third, loan purpose and loan type are important determinants of which syndicated loans are traded. Syndicated loans that are used for debt repayment, takeovers, and leveraged buyouts are more likely to be traded, while general corporate purpose loans are less likely to be traded. Term loans, which are typically fully drawn when the loan is closed, are more likely to be traded than undrawn, or partially drawn, revolvers. Also, we find that a borrower's industrial classification and loan origination year affect the likelihood of a syndicated loan being traded.

Fourth, lender type and the reputation of the lender also play a role in whether a loan is traded. Syndicated loans that are originated by more active lenders (both nonbank and bank), with greater reputation in the market, are more likely to trade compared to their smaller counterparts who typically lack reputational capital. We find that syndicated loans originated by more active nonbank lenders are more likely to trade than loans originated by active bank lenders. This result is not surprising, however, given nonbank lenders do not face the higher regulatory capital requirements that large bank lenders confront, and nonbank lenders have become increasingly more involved recently in the development of other traded capital market instruments (i.e., corporate debt and equity).

Finally, as suggested by anecdotal evidence and the popular business press, the price of a loan relative to par is an important determinant of whether a syndicated loan is traded. Given the recent interest rate environment and the search by investors for higher yields, we find that highly levered syndicated loans are more likely to be traded than levered loans, while non-levered loans with the lowest yields are the least likely to be traded.

This paper is organized as follows. Section 2 provides background information on the syndicated loan market and the recent surge in secondary market trading of syndicated loans. Section 3 describes our sample of syndicated loans and presents descriptive statistics on key features of traded and non-traded syndicated loans. Section 4 discusses the various specifications of the binomial logistic regression models that we estimate using borrower, lender, and loan characteristics and presents the parameter estimates. Finally, Section 5 provides a summary and conclusions and suggests future areas for empirical research.

\section{OVERVIEW OF SYNDICATED LENDING AND LITERATURE REVIEW}

\subsection{What is Syndicated Lending?}

A loan syndicate is a group of banks that jointly makes or underwrites a loan to a single commercial borrower. Loan syndicates are typically led by agent banks, which initially underwrite the credit and find participants willing to purchase shares of the credit and incur any associated pro-rata share of losses. The credit is governed by a common agreement and a single set of documentation. Syndicated loans can be either secured or unsecured, and typically hold priority over the claims of most other types of creditors. In theory, these creditors must be repaid before the claims of other junior creditors are satisfied.

Syndicated loans are typically floating-rate instruments that have an interest rate spread over LIBOR that compensates syndicate members for liquidity, market, and credit risk. Syndicated loans also have more numerous and rigid covenants than bonds, providing loan-holders considerable control and insight into a borrower's financial health. According to Assender (2000) and Miller (2004) loan covenants can include restrictions on current ratios, net worth and leverage ratios. Finally, syndicated loans are often callable without penalty, although prepayment penalties are increasingly being incorporated into loan agreements (Standard \& Poor's Leverage Lending 2003).

The shift towards syndicated lending from other forms of financing can be attributed to the fact that the syndicated loan market combines some of the most attractive features of commercial banking and investment banking. First, syndicated loans, like other types of bank loans, can be of any maturity, possess numerous covenants, and most importantly, provide the flexibility of changing and renegotiating contract features during the life of the loan. Similar to public-debt contracts, however, syndicated loans are typically longer-term, possess loose covenants, and are rarely restructured. ${ }^{3}$

\footnotetext{
${ }^{3}$ Berlin and Mester (1992) and Raja and Winton (1995) examine the characteristics of relationship lending and public debt markets.
} 
More importantly, like public-debt markets, syndicated lenders have recently found it advantageous not only to participate, but also to actively trade syndicated loans, in order to satisfy a growing institutional demand for the very attractive risk-return profile of these investments. According to Okel (2005), there are currently 10 to15 active U.S loan-trading desks. The increased trading activity is due in part, as noted by Yago and McCarthy (2004), to the fact that syndicated loans provide a greater return per unit of risk than many other fixed-income assets, and they also have low correlations with most other classes of assets. Institutional investors have become much more aware of the attractive features of syndicated loans. More than 140 institutional investors purchased levered syndicated loans in 1999, compared to only 20 in 1993 (Weidner 2000).

The two primary types of syndicated loan facilities are revolvers and term loans, with more specialized types in each of these two general categories. ${ }^{4}$ Revolvers are similar to extending debt in the form of credit cards because borrowers have the right, but not the obligation, to draw down a credit line. Revolvers are typically made to borrowers as a backup source of funds, typically for unforeseen working capital needs. These loans typically last only 364 days in order for lenders to avoid regulatory capital requirements on loan commitments of one year or longer. In contrast, term loans have longer maturities and typically are amortizing loans that can be classified further by their repayment schedules. For example, term A loans typically have a progressive amortizing repayment schedule, while institutional term loans, such as term B, C, and D loans, have longer amortization schedules.

In recent years, an increasing share of the U.S. corporate loan market has taken on many of the characteristics of a public capital market. With this change in the financial landscape, differences in the features of private finance (relationship bank loans) and public finance (corporate debt) discussed by Diamond (1991) and Boot and Thakor (2000) continue to disappear. ${ }^{5}$ Consistent with this trend, the syndicated loan market has gradually been developing qualities typically exhibited by public bond markets.

This progression is most readily apparent in the individual loan ratings assigned by both Moody's and Standard \& Poor's. These loan ratings were initiated in 1996, and during the past nine years, corporations have actively solicited and paid for loan ratings, which has greatly enhanced the liquidity of these syndicated loans. Given the low returns of money and bond funds in 2004 and 2005, mutual funds such as Putnam Investment, MFS Investment Management, and Pioneer Investment Management have created bank-loan funds that have recently generated higher yields (Opydke 2005). These bank-loan funds, along with the investors in them, have been attracted to syndicated loans not only by their higher yields, but also by the senior (and often secured) nature of these loans, their default recovery statistics, and their attractiveness as investments in a rising rate environment.

Banks have benefited from this broadening of the syndicated loan market and their increased ability to sell and securitize loan syndications in several ways. Pennachi (1988) and Demsetz (2000) observe that loan syndications are a cost-effective method for participating banks to achieve portfolio diversification and to exploit any funding advantages. Syndicated lending also allows banks to compete more effectively with public debt markets for corporate borrowers. To a large degree, the development of the loan syndication market has stemmed, if not reversed, the trend toward disintermediation of corporate debt. Finally, an active syndicated loan secondary market enables agent banks to leverage their expertise in loan origination and fee collection for structuring, distributing, and servicing the larger syndicated credits, while shedding much of the credit risk, thus providing a mechanism to manage interest rate risk and avoid current capital requirements on loans held in portfolio.

\footnotetext{
${ }^{4}$ For more details on specialized loan types, such as multicurrency revolvers, standby facilities, and swing-line facilities, see "The U.S. Leveraged Loan Market," Milken Institute, 2004.

5 Similar types of changes are also occurring in the small business loan market, as changes in technology and increased competition have caused lenders to rely more on quantitative or "hard" information to underwrite and price these credits. Specifically, the increased use of credit scoring models in making loans to small and mid-size borrowers has led many lenders, especially the larger ones, to rely more on hard information and less on qualitative or "soft" relationship-based information. Despite these shifts in small business underwriting and pricing, active trading and securitization of smaller loans is very rare. See Berger, Frame, and Miller (2002) for details on the use of credit scoring models in small business lending.
} 
Besides the benefits of loan syndications and the active trading of these loans in the secondary market, there are also costs. There has been an unbundling of the business of syndicated lending, and traditional buy and hold banks have seen their spread revenue decline as the syndicated loan market has become more competitive. ${ }^{6}$ Today, the syndicated loan market consists of several distinct activities, including client management/asset origination, credit rating valuation, portfolio investment, credit ALCO, and servicing. ${ }^{7}$ This ongoing unbundling of financial activities in the syndicated loan market will result in more specialized and efficient syndicated lending. ${ }^{8}$

\subsection{Syndicated Loan Trading in the Secondary Market}

The development of the syndicated loan market can be grouped into three phases. Credit syndications first emerged in the 1970s as a sovereign business. During this period, loans were made to developing countries in Asia, Africa, and Latin America. Syndicated lending to these borrowers replaced bilateral lending. During the 1980s, however, the payment difficulties experienced by emerging country borrowers, such as Mexico, Argentina, Venezuela and the Philippines, led to substantial write-downs by the larger banks (an effort led by Citibank), resulting in the eventual restructuring of these loans into bonds (e.g., Brady Bonds).

This restructuring of loans into bonds initially led to a decrease in syndicated lending and more bond financing. However, this change also provided the impetus for the use of more sophisticated risk pricing tools and covenants that were developed in the bond market (Gadanecz (2004). These developments eventually led to increased syndicated lending during the 1990s, a period during which syndicated loans became the largest source of U.S. corporate funding (Paine Webber (1999).

As more borrower data became available, and bank lenders acquired greater sophistication in making syndicated loans, nonbank firms became more active participants in the syndicated loan market. Given that banks do not like to hold poorly performing loans in their portfolios, most of the early syndicated loan trading was in distressed loans (i.e., loans trading at less than 90 percent of their par value). According to the Loan Pricing Corporation, the volume of distressed loan trading from 1991 to 1994 was greater than the volume of loans traded at par, as banks sold their poorly performing syndicated credits in the secondary market.

During the early 1990s, trading desks specializing in distressed loans emerged at several of the larger U.S. financial institutions (Miller (1998). These institutions acted primarily as loan brokers rather than traders. By the latter part of the 1990s, the success of the distressed loan market led to more than 30 active loan traders (e.g., JP Morgan Chase, Citigroup, Deutsche Bank, CFSB, and Goldman Sachs) becoming involved in the syndicated loan market (Taylor and Yang (2004) and dealing in a wide range of syndicated loan credit quality.

Many factors have contributed to the rapid development of the secondary market trading of U.S. corporate syndicated loans. Economic growth, interest rate cycles, changes in bank capital and regulatory rules, rating agency involvement, and a growing institutional investor appetite for the high returns associated with leveraged syndicated loans are some of these factors (McAdams (2005). For example, the implementation of Basel I in 1992 produced some of the earliest impetus for secondary market activity by providing incentives to commercial banks to shift some of their loans off their balance sheets in order to avoid increased regulatory capital requirements. These trends have led investment banks, whose expertise is the bond market, to become more active in the syndicated loan market. The broadening of the secondary market has led to a more efficient institutional sharing of credit risk in syndicated loans.

\footnotetext{
${ }^{6}$ This earnings pressure has led to consolidation among some of the larger agent banks and syndicate participants.

${ }^{7}$ Client management focuses on sales and pricing deals that exceed the required hurdle rate. The valuation role involves establishing an objective risk rating independent of loan origination and portfolio management. So-called credit ALCO focuses on an institution's permissible credit targets and is similar to ALCO concerns with interest rate risk. See "Active Credit Portfolio Management," ERISK, July 1, 1998 for more details.

${ }^{8}$ This unbundling of financial activities is very similar to the transformation that occurred in the U.S. mortgage market. Twentyfive years ago, most commercial banks and thrifts were responsible for underwriting, funding, servicing, monitoring and loan workout. Today, these roles are been unbundled, with Fannie Mae and Freddie Mac actively purchasing mortgage loans, which are then securitized and sold in the secondary market.
} 
One of the primary factors behind this was the creation of the Loan Syndications and Trading Association (LSTA) in 1995. Although the LSTA started as an association for traders, it quickly became a key advocate for improving liquidity, efficiency, and transparency in the secondary market for syndicated loans by standardizing documentation and promulgating best practices. Since its creation, LSTA has developed over 26 standardized documents that have helped to facilitate the process of transferring loans from the primary to the secondary market and to eliminate market disputes in secondary market trading. In 2004, LSTA also completed a pilot program to assign CUSIPs to syndicated loans in order to improve the transactional efficiency of syndicated lending and the secondary market trading of these credits (Standard \& Poor's (2004). As a result, the documentation and distribution protocols required of agent banks have been greatly reduced, while the issue of tracking syndicated credits has been greatly reduced.

\section{DATA AND DESCRIPTIVE STATISTICS}

In this section, we describe the selection of our sample of syndicated loans. We also present descriptive statistics on key characteristics of traded and non-traded syndicated loans. We also discuss the variables used in our binomial logistic regression models.

\subsection{Data}

Our empirical work uses a data set of syndicated loans constructed from several different files of Loan Pricing Corporation (LPC or Dealscan) data. The data consist of 39,262 U.S. corporate syndicated loan facilities originated over the period 1997 to $2003 .{ }^{9}$ Of this total number, 2,779 loans are traded in the secondary market during the sample period. The Dealscan database has been used in several studies that examine loan-level transactions, including Dennis and Mullineaux (2000), Hubbard, Kuttner, and Palia (2002), and Lee and Mullineaux (2004). Recently, however, the Dealscan database started to distribute a loan-trading file that includes information on syndicated loans that trade. To our knowledge, our study is one of the first empirical analyses to use this new loan trading data and to examine the extent and determinants of the trading activity associated with syndicated loans.

In constructing our sample of syndicated loans, we combined a set of information variables from various Dealscan data files. The data hierarchy involves corporate borrowers that have deals outstanding and deals that consist of tranches or facilities. The secondary market data identifies loans by Loan Identification Number (LINs). Dealscan has a data table that allows the mapping of facilities to Facility Identification Numbers (FINs). We produce our sample of loans by matching the secondary market trading data with the Dealscan data using these two loan identification codes (i.e., LIN=FIN). ${ }^{10}$

\subsection{Descriptive Statistics for Our Sample of Syndicated Loans}

Table 1 presents descriptive statistics on the syndicated loans in our sample. The loans are divided into traded and non-traded syndicated loans over the period 1997 to 2003. Panel A of Table 1 shows a loan's trading status by the commencement date of the facility. We classify a syndicated loan as traded if there is any secondary market trading over the sample period. This data filtering produces a sample of 2,779 syndicated loans, roughly 7 percent of the total sample of loans, which can be classified as traded in the secondary market.

Panel B of Table 1 presents several attributes of the underwriting syndicate and the trading status of the syndicated loans. Lee and Mullineaux (2004) show that commercial lending syndicates are smaller and more concentrated, when there is little information about the borrower and credit risk is high. The results in Panel B provide support for their result. First, the average number of syndicate members for traded loans is significantly

\footnotetext{
${ }^{9}$ Although our focus is on the U.S. syndicated loan market, a global market is also beginning to emerge for these loans. For example, Kihara (2005) notes the growth of the Japanese primary loan market and provides anecdotal evidence of an expanding secondary market for trading these loans. Given our sample period, however, it did not make sense to include non-U.S. borrowers due to the limited amount of trading activity, and so we limited our sample to syndicated loans made to U.S. corporate borrowers.

${ }^{10}$ A small number of traded loans with missing linking information (i.e., LINs) were manually matched by the authors.
} 
larger (11.5 members vs. 6.6 members) than for non-traded loans. Second, there is evidence that traded loans are less opaque than non-traded loans, given their significantly greater average loan size (\$285 million vs. \$218 million) and significantly longer maturity (69 months vs. 47.5 months).

Panel B of Table 1 also presents information on the number of loan facilities that have a ticker (TICKER=1, if the borrower has a ticker symbol, 0 otherwise), a public debt rating (RATING=1, if there is a Moody's or Standard \& Poor's rating for the borrower, 0 otherwise), if the loan is secured (SECURED=1, if the loan is collateralized, 0 otherwise) and the borrower's annual sales (SALES = natural logarithm of the borrower's annual sales at the end of the quarter prior to loan syndication). Aproximately 47 percent of the syndicated loans in our sample are made to a borrower that has a ticker symbol, and therefore traded equity.

Table 1 examines loan facility trading status by commencement date, borrower and lender attribute, loan type, loan purpose and borrower industrial classification.

While the majority of traded loans do not have a borrower debt rating, over 32 percent of the traded loans have a debt rating, compared to only 17 percent for the non-traded loans. Thus, the presence of a debt rating (i.e., more market information) appears to increase the likelihood of a loan being traded. A limited number of borrowers report information on collateral and firm sales. Over 94 percent of the traded loans that have collateral information are secured, compared to only 73 pecent of their non-traded counterparts. This suggests that the presence of collateral is important to secondary market loan participants. Finally, for the subsample of borrowers reporting sales, borrowers whose loans trade have slightly greater sales than their non-traded counterparts (20.4 vs 19.8).

As shown in Panel C of Table 1, loan maturity is closely tied to loan purpose. Most traded syndicated loans are term loans, followed by revolving loans with maturities greater than one year. Most term loans have set amortization schedules and are fully drawn at closing. Both of these attributes are attractive to secondary market participants. Thus, it is not surprising that almost 16 percent of term loans are traded compared to only about 4 percent of long term revolvers. In addition, syndicated credits structured as short term instruments, such as revolvers with maturity less than one year and 364-day facilities, are much less likely to be traded ( 0.2 percent and 0.9 percent, respecitvely).

Panel D of Table 1 groups the sample of syndicated loans by trading status and the borrower's primary industrial classification. Both traded and non-traded syndicated loans cover a wide variety of industrial classifications. These industrial classifications are IND_2 = mining, IND_3 = construction, IND_4 = manufacturing, IND_ $5=$ transportation, communication, and public utilities, IND_6 $=$ wholesale trade, IND_7 = retail trade, IND_8 = finance, insurance, and real estate, and IND_All_Other $=$ agriculture, services, and government. These industry variables are also used in our logistic regressions to control for differences in collateralization and risk across industry groups.

In a recent study, Gonas, Highfield, and Mullineaux (2004) show that these industry variables affect whether a syndicated loan is secured. There is a fairly wide variation in the proportion of loans traded by industrial classification, ranging from 1.4 percent for wholesale trade to over 10 percent for mining and retail trade. Most of the differences in the percentages of traded and non-traded loans by industrial classification are significant at the 5 percent level.

Finally, Panel E of Table 1 presents information on loan purpose for the full sample and by loan trading status. Several studies have included loan purpose in studying the determinants of syndicated loan pricing, which is closely tied to loan trading (e.g., Hubbard, Kuttner, and Palia (2002) and Yi and Mullineaux (2004)). General corporate purpose loans, the most popular loan type, cover a broad range of loan purposes, including working capital loans. Debt repayment is the second most popular stated purpose, followed by takeover and working capital. As shown in Panel B, the majority of loan commitments are mostly medium- to long-term contracts with an average contract period of about four years. Two loan purposes that are typically associated with more credit risk, and therefore higher yield, are takeover (20.3 percent) and leveraged-buyout (29.3 percent) loans. As Table 1 shows, these loans are significantly more likely to be traded loans. 
Table 1: Syndicated Loan Descriptive Statistics by Trading Status

\begin{tabular}{|c|c|c|c|c|}
\hline \multicolumn{5}{|c|}{ Panel A. Trading Status by Facility Commencement Date } \\
\hline Year & $\begin{array}{l}\text { Total Number of } \\
\text { Traded Loans }\end{array}$ & \multicolumn{2}{|c|}{$\begin{array}{c}\text { Total Number of } \\
\text { Non- Traded Loans }\end{array}$} & Total \\
\hline 1997 & 301 & \multicolumn{2}{|c|}{6,756} & 7,057 \\
\hline 1998 & 532 & \multicolumn{2}{|c|}{5,503} & 6,035 \\
\hline 1999 & 499 & \multicolumn{2}{|c|}{4,980} & 5,479 \\
\hline 2000 & 455 & \multicolumn{2}{|c|}{4,975} & 5,430 \\
\hline 2001 & 328 & \multicolumn{2}{|c|}{4,367} & 4,695 \\
\hline 2002 & 315 & 4,842 & & 5,157 \\
\hline 2003 & 349 & \multicolumn{2}{|c|}{5,060} & 5,409 \\
\hline Total & $2,779(7.1 \%)$ & $36,483(92.9 \%)$ & \multicolumn{2}{|r|}{39,262} \\
\hline \multicolumn{5}{|c|}{ Chi-Square Test for Difference $(<.0001)$} \\
\hline \multicolumn{5}{|c|}{ Panel B. Loan Syndicate Descriptive Statistics by Trading Status } \\
\hline & & Traded & Non-Trade & Total \\
\hline Mean \# & nembers & 11.5 & $6.6^{*}$ & 6.9 members \\
\hline Mean Fa & & 285 million & $\$ 218$ million* & $\$ 222$ million \\
\hline Maturity & & 69.0 months & 47.5 months* & 49.0 months \\
\hline Ticker $=$ & & $49.4 \%(n=1,372)$ & $47.4 \%(\mathrm{n}=17294)$ & $47.5 \%(\mathrm{n}=18666)$ \\
\hline Ticker $=$ & & $50.6 \%(\mathrm{n}=1,407)$ & $52.6 \%(n=19189)$ & $52.5 \%(\mathrm{n}=20596)$ \\
\hline Rating $=$ & & $32.3 \%(\mathrm{n}=898)$ & $17.1 \%(\mathrm{n}=6237)$ & $18.2 \%(\mathrm{n}=7135)$ \\
\hline Rating $=$ & & $67.7 \%(\mathrm{n}=1881)$ & $82.9 \%(\mathrm{n}=30246)$ & $81.8 \%(n=32127)$ \\
\hline Secured & & $93.4 \%(\mathrm{n}=2217)$ & $73.9 \%(n=12610)$ & $76.2 \%(n=14689)$ \\
\hline Secured $=$ & & $6.2 \%(\mathrm{n}=138)$ & $26.1 \%(\mathrm{n}=4461)$ & $23.8 \%(\mathrm{n}=4599)$ \\
\hline Mean Lo & & $20.4(n=2505)$ & $19.8 *(n=24954)$ & $19.9(\mathrm{n}=27459)$ \\
\hline \multicolumn{5}{|c|}{ Panel C. Syndicated Loan Type by Trading Status } \\
\hline Term & & $1,873(15.8 \%)^{*}$ & $9,984(84.2 \%)$ & 11,587 \\
\hline Revolver & & $642(4.4 \%)^{*}$ & $14,013(95.6)$ & 14,655 \\
\hline Revolve & & $2(.2 \%)^{*}$ & $958(99.8)$ & 960 \\
\hline 364 Day & & $52(.9 \%)^{*}$ & $5,410(99.0)$ & 5,462 \\
\hline All Othe & bans 1 & $210(3.3 \%)^{*}$ & $6,118(96.6)$ & 6,328 \\
\hline \multicolumn{5}{|c|}{ Panel D. Industrial Classification by Trading Status } \\
\hline IND_2 ( & & $538(10.0 \%)^{*}$ & $4,820(90.0)$ & 5,472 \\
\hline IND_3 ( & & $608(7.9)^{*}$ & $7,054(92.1)$ & 7,818 \\
\hline IND_4 ( & & $620(9.3)^{*}$ & $6,015(90.7)$ & 6,789 \\
\hline IND_5 ( & , and Pub Util) & $265(6.7)$ & $3,675(93.3)$ & 3,955 \\
\hline IND_6 ( & ade) & $106(1.4)^{*}$ & $7,470(98.6)$ & 7,576 \\
\hline IND_7 ( & & $362(10.1)^{*}$ & $3,210(89.9)$ & 3,572 \\
\hline IND_8 (1 & and Real Estate) & $187(9.66)$ & $1,741(90.3)$ & 1,928 \\
\hline All Othe & ces, and Govt) & $93(2.8)^{*}$ & $3,181(97.1)$ & 3,393 \\
\hline \multicolumn{5}{|c|}{ Panel E. Syndicated Loan Purpose by Trading Status } \\
\hline Corporat & & $309(3.0 \%)^{*}$ & $10,036(97.0 \%)^{*}$ & 10,345 \\
\hline Debt & & $526(6.6)^{*}$ & $7,472(93.4)^{*}$ & 7,998 \\
\hline TAKEO & & $716(20.3)^{*}$ & $2,802(79.6)^{*}$ & 3,518 \\
\hline $\mathrm{LBO} / \mathrm{MH}$ & & $524(29.3) *$ & $1,261(70.7)^{*}$ & 1,785 \\
\hline Other $\mathrm{Pu}$ & & $704(4.5)^{*}$ & $14,912(95.5)^{*}$ & 15,616 \\
\hline
\end{tabular}

1 All other includes loan types such as acquisition facilities, bankers acceptances, bridge loans, debt restructurings, notes, and standby letters of credit.

2 Other industrial classifications include agriculture, insurance, real estate, and missing.

3 Other less populated loan purposes include Acquisition lines, CP backups, capital expenditures, credit enhancements, debtor in possessing financing, Notes ESOPs, equipment purchases, IPO related, lease and trade financing, real estate receivables, and other.

* denotes significance at the 5 percent level. 
Table 2 presents pricing information for a subset of syndicated loans in our sample because pricing information is not available for all loan facilities in Dealscan. Some syndicated loans are often priced higher (i.e., levered and highly levered) than others, so it is important to control for this in empirical work. We use Loan Pricing Corporation's definitions of levered and highly levered syndicated loans. Levered syndicated loans are those with an all-in-drawn pricing of at least LIBOR plus 125 basis points, while highly levered loans are those with all-in-drawn pricing of at least LIBOR plus 250 basis points.

Panel A of Table 2 presents this pricing information by cohort year, while Panel B reports this information for all years. Pricing information is only available for a subsample of 18,805 loans starting in 1998. Of this number, the number of traded loans falls from 2,779 to 1,702 loans. Panel A of Table 2 shows a substantial increase in the number of both levered and highly levered syndicated loans originated in 1999 and 2000. The number drops off substantially in 2001, and continues to fall in both 2002 and 2003. Panel B of Table 2 shows that of the traded syndicated loans over the period 1998 to 2003, approximately 20 percent are either levered or highly levered.

Table 2: Loan Pricing Information by Trading Status

\begin{tabular}{|c|c|c|c|}
\hline \multicolumn{4}{|c|}{ Panel A. Loan Pricing Information, By Cohort Year } \\
\hline & Traded & Non-Traded & Total \\
\hline \multicolumn{4}{|c|}{1998} \\
\hline Non-Levered & 12 & 951 & 963 \\
\hline Levered & 81 & 713 & 794 \\
\hline Highly Levered & 166 & 767 & 933 \\
\hline \multicolumn{4}{|c|}{1999} \\
\hline Non-Levered & 15 & 1,240 & 1,255 \\
\hline Levered & 70 & 806 & 876 \\
\hline Highly Levered & 364 & 1,552 & 1,916 \\
\hline \multicolumn{4}{|c|}{2000} \\
\hline Non-Levered & 17 & 1,543 & 1,560 \\
\hline Levered & 60 & 874 & 934 \\
\hline Highly Levered & 354 & 1,491 & 1,845 \\
\hline \multicolumn{4}{|c|}{2001} \\
\hline Non-Levered & 30 & 1,306 & 1,336 \\
\hline Levered & 42 & 710 & 752 \\
\hline Highly Levered & 208 & 1,170 & 1,378 \\
\hline \multicolumn{4}{|c|}{2002} \\
\hline Non-Levered & 13 & 1,139 & 1,152 \\
\hline Levered & 37 & 744 & 781 \\
\hline Highly Levered & 175 & 1,349 & 1,524 \\
\hline \multicolumn{4}{|c|}{2003} \\
\hline Non-Levered & 0 & 215 & 215 \\
\hline Levered & 7 & 187 & 194 \\
\hline Highly Levered & 51 & 340 & 391 \\
\hline \multicolumn{4}{|c|}{ Panel B. Pricing Information, All Years } \\
\hline Non-Levered & 6,394 & 87 & 6,481 \\
\hline $\begin{array}{l}\text { Levered } \\
\mathbf{1 2 5}<\text { allinspread }<\mathbf{2 5 0}\end{array}$ & 297 & 4,034 & 4,331 \\
\hline $\begin{array}{l}\text { Highly Levered } \\
\text { allinspread >=250 }\end{array}$ & 1,318 & 6,669 & 7,987 \\
\hline Total & 1,702 & 17,103 & 18,805 \\
\hline
\end{tabular}

Table 3 presents additional loan information for this subsample by pricing type (i.e., non-levered, levered, and highly levered). Panel A shows that the average loan amount declines with increases in loan prices. For example, the average loan amount is $\$ 486$ million for non-levered loans, compared to $\$ 148$ and $\$ 92$ million for levered and highly levered loans. Second, Panel A shows that highly levered loans have longer maturities (49.1 months) than levered (48.9 months) and non-levered (32.3 months) loans. Panel A also shows that there is an 
inverse relationship between a senior debt rating, RATING, and whether the borrower has a ticker symbol, TICKER. For non-levered loans, 60.8 percent have a ticker and 32.4 percent have a debt rating, compared to 47.9 percent and 13.5 percent for highly levered loans. Finally, Panel A of Table 3 shows that borrower sales decline with increases in loan prices. This is not surprising, because sales are often used as a proxy for firm size and risk. It follows, therefore, that loans made to smaller, riskier borowers will have higher interest rates.

Panel B of Table 3 shows wide variation in pricing by loan type. Over 60 percent of term loans (TERM) are highly levered, compared to less than 50 percent for all other reported loan types. For 364 day loan facilities, only 6 percent are higly levered. Panel $\mathrm{C}$ of Table 3 shows similar pricing variation by borrower industrial classification. For example, the majority of loans (54.1 percent) in wholesale trade (IND_6) are non-levered, while in construction (IND_3) and finance, insurance and real estate (IND_8), the majority (53.4\% and 53.5\%) of loans are highly-levered. Finally, Panel D of Table 3 shows that there is also wide variation in pricing by loan purpose. The largest categories for non-levered loans are corporate (39.3 percent) and all other (42.4 percent), while over 85 percent of all LBO/MBO loans are highly levered.

Table 3: Loan and Borrower Information by Pricing Status

\begin{tabular}{|c|c|c|c|}
\hline \multicolumn{4}{|c|}{ Panel A. Loan Attribute } \\
\hline & $\begin{array}{c}\text { Non-levered } \\
\mathrm{N}=6481\end{array}$ & $\begin{array}{c}\text { Levered } \\
\mathrm{n}=4331\end{array}$ & $\begin{array}{c}\text { Highly levered } \\
\mathrm{n}=7987\end{array}$ \\
\hline Average loan amount & 486 million & 148 million & 92 million \\
\hline Maturity & 32.3 months & 48.9 months & 49.1 months \\
\hline Ticker $=1$ & $60.8 \%(n=3942)$ & $54.3 \%(\mathrm{n}=2349)$ & $47.9 \%(n=3827)$ \\
\hline Ticker $=0$ & $39.2 \%(\mathrm{n}=2539)$ & $45.8 \%(n=1982)$ & $52.1 \%(\mathrm{n}=4160)$ \\
\hline Rating $=1$ & $32.4 \%(n=2101)$ & $16.7 \%(\mathrm{n}=724)$ & $13.5 \%(\mathrm{n}=1075)$ \\
\hline Rating $=0$ & $67.6 \%(n=4380)$ & $83.3(n=3607)$ & $86.5 \%(n=6912)$ \\
\hline Secured $=1$ & $30.4 \%(\mathrm{n}=638)$ & $82.5 \%(n=1920)$ & $95.8 \%(\mathrm{n}=4937)$ \\
\hline Secured $=0$ & $69.6 \%(n=1461)$ & $17.5 \%(\mathrm{n}=408)$ & $4.21 \%(n=217)$ \\
\hline Average Log (Borrower Sales) & 21.3 & 19.6 & 19.0 \\
\hline \multicolumn{4}{|c|}{ Panel B. Loan Type by Pricing } \\
\hline Term & 14.3 percent & 22.6 percent & 63.1 percent \\
\hline Revolver $>=1$ Year & 29.6 & 28.3 & 42.0 \\
\hline Revolver $<1$ Year & 28.9 & 21.6 & 49.6 \\
\hline 364 Day Facility & 83.1 & 10.8 & 6.0 \\
\hline All Other Types of Loans 1 & 34.8 & 22.9 & 42.3 \\
\hline \multicolumn{4}{|c|}{ Panel C. Industrial Classification by Pricing } \\
\hline IND_2 (Mining) & 34.8 percent & 19.9 percent & 45.3 percent \\
\hline IND_3 (Construction) & 26.2 & 20.5 & 53.4 \\
\hline IND_4 (Manufacturing) & 42.2 & 18.6 & 39.2 \\
\hline IND_5 (Trans, Comm, and Pub Util) & 25.9 & 28.4 & 45.8 \\
\hline IND_6 (Wholesale Trade) & 54.1 & 26.9 & 18.9 \\
\hline IND_7 (Retail Trade) & 22.9 & 21.4 & 55.8 \\
\hline IND_8 (Finance, Ins, and Real Estate) & 22.2 & 24.4 & 53.5 \\
\hline All Other (Agr, Services, and Govt) & 31.7 & 30.5 & 37.8 \\
\hline \multicolumn{4}{|c|}{ Panel D. Loan Purpose by Pricing } \\
\hline Corporate & 39.3 percent & 23.4 percent & 37.3 percent \\
\hline Debt & 26.4 & 27.9 & 45.6 \\
\hline Takeover & 24.8 & 22.9 & 52.3 \\
\hline LBO/MBO & 0.7 & 13.6 & 85.7 \\
\hline Other Purpose & 42.4 & 21.8 & 35.8 \\
\hline
\end{tabular}

Table 3 examines loan and borrower attributes by the facilities pricing status, i.e., non-levered, levered, or highly levered. For syndicated loans with pricing information, we use Loan Pricing Corporation's definitions of levered loans as ones with an all-in-drawn pricing of the London Interbank Offer Rate (LIBOR) plus 125 basis points, and highly levered loans as ones with all-in-drawn spreads in excess of LIBOR plus 250 basis points. 


\section{DETERMINANTS OF THE SECONDARY MARKET TRADING OF SYNDICATED LOANS}

In this section, we specify binomial logistic regression models to examine the determinants of which syndicated loans are most likely to be traded in the U.S. secondary market. We estimate three different logistic regression models using our sample of syndicated loans for the period 1997 to 2003 . The dependent variable in all logistic regression specifications is a binary variable that denotes whether a syndicated loan is traded (TRADED=1) or non-traded (TRADED $=0$ ) in the secondary market at any time over the sample period. In specifying the logistic regression models, we include explanatory variables that account for important borrower, lender, and loan characteristics that are likely to determine whether a syndicated loan is traded in the secondary market.

\subsection{Regression Control Variables}

In this section, we discuss control variables used in the logistic regression models. We group these variables into those related to borrower-, lender-, and loan-level variables. Table 4 presents a brief description of all the variables used in the logistic regression models.

Table 4 includes a description of all variables used in the logistic regression models.

Table 4: Description of Regression Variables

\begin{tabular}{|c|c|}
\hline Variable & Description \\
\hline \multicolumn{2}{|r|}{ Panel A. Loan Characteristics } \\
\hline TRADED & Dummy variable equal to 1 if the loan was traded over the sample period, and 0 otherwise. \\
\hline MATURITY & Maturity of the loan in months \\
\hline SECURED & Dummy variable equal to 1 if the loan is collateralized, and 0 otherwise. \\
\hline PURPOSE_CORP & Dummy variable equal to 1 if the loan is for corporate purpose, and 0 otherwise \\
\hline PURPOSE_DEBT & Dummy variable equal to 1 if the loan is for debt purpose, and 0 otherwise \\
\hline PURPOSE_TO & Dummy variable equal to 1 if the loan is for takeover, and 0 otherwise \\
\hline PURPOSE_LBO/MBO & Dummy variable equal to 1 if the loan is for $\mathrm{LBO} / \mathrm{MBO}$, and 0 otherwise \\
\hline TERM & Dummy variable equal to 1 if the loan is a term loan, and 0 otherwise \\
\hline REVOLVER & $\begin{array}{l}\text { Dummy variable equal to } 1 \text { if the loan a revolver with a maturity greater than } 12 \text { months, and } 0 \\
\text { otherwise }\end{array}$ \\
\hline REVOLVER_LT_1YR & Dummy variable equal to 1 if the loan is a revolver with a maturity less than 1 year, and 0 otherwise \\
\hline FACILITY_364 & Dummy variable equal to 1 if the loan is a 364 day facility, and 0 otherwise \\
\hline LN_FACILITY_AMT & Natural logarithm of the dollar value of the size of the loan facility. \\
\hline LEVERED & Dummy variable equals 1 if the all-in-spread is between 125 and 249 , and 0 otherwise \\
\hline HIGHLY_LEVERED & Dummy variable equals 1 if the all-in-spread is greater than 249 , and 0 otherwise \\
\hline \multicolumn{2}{|r|}{ Panel B. Borrower Characteristics } \\
\hline RATING & Dummy variable equal to 1 if the borrower has a senior debt rating, and 0 otherwise. \\
\hline TICKER & Dummy variable equal to 1 if the borrower has a ticker symbol, and 0 otherwise. \\
\hline LN_SALES & Natural logarithm of the borrower's annual sales at the end of the quarter prior to syndication. \\
\hline IND_2 & Dummy variable equal to 1 if the borrower's industrial classification is mining, and 0 otherwise \\
\hline IND_3 & $\begin{array}{l}\text { Dummy variable equal to } 1 \text { if the borrower's industrial classification is construction, and } 0 \\
\text { otherwise }\end{array}$ \\
\hline IND_4 & $\begin{array}{l}\text { Dummy variable equal to } 1 \text { if the borrower's industrial classification is manufacturing, and } 0 \\
\text { otherwise }\end{array}$ \\
\hline IND_5 & $\begin{array}{l}\text { Dummy variable equal to } 1 \text { if the borrower's industrial classification is transportation, } \\
\text { communication and public utility, and } 0 \text { otherwise }\end{array}$ \\
\hline IND_6 & $\begin{array}{l}\text { Dummy variable equal to } 1 \text { if the borrower's industrial classification is wholesale trade, and } 0 \\
\text { otherwise }\end{array}$ \\
\hline IND_7 & Dummy variable equal to 1 if the borrower's industrial classification is retail trade, and 0 otherwise \\
\hline IND_8 & $\begin{array}{l}\text { Dummy variable equal to } 1 \text { if the borrower's industrial classification is finance, insurance, and real } \\
\text { estate, and } 0 \text { otherwise }\end{array}$ \\
\hline \multicolumn{2}{|r|}{ Panel C. Lender Characteristics } \\
\hline N_SYN & Number of syndicate members \\
\hline BIG_BANK & $\begin{array}{l}\text { Dummy variable equal to } 1 \text { if the facility was agented by a top } 10 \text { commercial bank, and } 0 \\
\text { otherwise. }\end{array}$ \\
\hline BIG_NONBANK & Dummy variable equal to 1 if the facility was agented by a top 3 investment bank, and 0 otherwise. \\
\hline
\end{tabular}




\subsubsection{Loan-Level Variables}

Two important loan-level attributes that we expect to affect whether a syndicated loan is traded are the natural logarithm of loan size, LN_FACILITY_AMT, and the loan's original maturity, MATURITY. With regard to loan size, we expect larger loans to be made to larger, less opaque borrowers, and hence these loans are more likely to be traded in the secondary market. We expect a postive coefficient on loan size. Simarly, we expect shorter-term loans to be made to riskier, more opaque borrowers. Because these loans are less likely to be traded in the secondary market, we expect a positive coefficient on maturity.

The Dealscan database includes a wide variety of loan purposes and loan types that we use as control variables in the logistic regression models. Some of these loan types are associated with loan maturity. For example, we expect loan types associated with shorter maturities, such as short-term revolvers, REVOLVER_LT_YR and 364-day facilities, FACILITY_364, to be less likely to trade, because these are shorter term loan commitments that do not require an active secondary market. We also include variables that capture whether the loan is a term loan, TERM, or a note, NOTE. We expect term loans of a specific term with periodic payments to be the most likely type of loan to be traded. Thus, we expect a postive coefficient on TERM. In contrast, it is unlikely that notes will be traded in the secondary market, and so we expect a negative coefficient on NOTE.

Finally, we include several loan purpose variables in our logistic regressions, because loan purpose is likely to impact whether a loan is traded. Because debt-repayment, PURPOSE_DEBT, is typically risky and associated with longer term financing, we expect a positive coefficient on this variable. Similarly, investors in the secondary market are more likely to have a demand for riskier loan types, such as LBOs, PURPOSE_LBO, and takeovers, PURPOSE_TO, beause of the higher yields on these loans. Thus, we expect a positive coefficient on these variables. In contrast, standard corporate purpose debt loans, with lower yields, are less likely to be traded, and hence we expect a negative coefficient on this variable.

For a subsample of syndicated loans over the period 1998 to 2003, we also include pricing information as right-hand variables in our logistic regressions. Anecdotal evidence and the univariate statistics reported above suggest that levered and highly levered loans dominate the secondary market trading of syndicated loans. Thus, we include whether the loan is levered, LEVERED, or highly levered, H_LEVERED, using Loan Pricing Corporation's definition of levered- and highly- levered-loans. We expect a positive coefficient on both of these variables.

To check for the robustness of the parameter estimates, we also examine a subsample of borrowers for which we have additional loan-level data. For these loans, we include a variable that captures whether the loan is collateralized (SECURED=1, if loan is collateralized, 0 otherwise). We expect the coefficient on SECURED to be positive, because the presence of collateral lowers the likelihood of losses to investors in the event of default.

\subsubsection{Borrower-Level Variables}

To control for borrower differences across industries and time, industrial classification variables and year dummy varaibles are included. As indicated above, the industrial classification variables are IND_2 = mining, IND_3 = construction, IND_4 = manufacturing, IND_ $5=$ transportation, communication, and public utilities, IND_6 $=$ wholesale trade, IND_7 $=$ retail trade, IND_8 $=$ finance, insurance, and real estate, and IND_All_Other = agriculture, services, and government. Also, because interest rates and trading activity in syndicated lending change over time, we include year dummy variables DUMMY_1998, DUMMY_1999, DUMMY_2000, DUMMY_2001, DUMMY_2002, and DUMMY_2003.

In order to control for the amount of information about a loan that is available in our logistic regressions, we include three information-related proxy variables. The first proxy for the level of information is RATING, an indicator variable that equals one if the borrower has a debt rating, and zero otherwise. The second proxy for information is TICKER, an indicator variable equal to one if the firm has equity trading, and zero otherwise. The third proxy for information is the natural logarithm of annual borrower sales, LN_SALES. Positive coefficients on these variables would indicate that loans made to borrowers with more information available to investors are more likely to be traded in the secondary market. 


\subsubsection{Lender-Level Variables}

To control for the impact of both lender size and syndicate size, we use variables that capture whether a large bank lender, BIG_BANK, or large nonbank lender, BIG_NONBANK, agented the loan deal. These two variables capture the effects on loan trading associated with the largest bank and nonbank lenders in the syndicated loan market. The bank variable controls for the largest ten agent banks, while the nonbank variable controls for the largest three nonbank lenders. We use the number of agented syndicated loans made by lenders over the sample period to rank the bank and nonbank lenders. We expect that the larger lenders in the syndicated loan market are more involved in the syndicated loan market, and thus more active in trading their syndicated loans.

Finally, we also include the number of participants in the underwriting syndicate, N_SYN, because we expect larger syndicates to have an agent or partipicant that is more likely to have secondary market ties. We expect a postive coefficent on this variable.

\subsection{Empirical Results}

Table 5 reports estimation results for the three different binomial logistic regression specifications. Logistic regression model 1 is estimated over the period 1997 to 2003. This regression specificiation includes loan-, borrower-, and lender-level information and year dummies. To further examine the robustness of our results, logistic regression model 2 is estimated on a subsample of loans that includes pricing information over the period 1998 to 2003. Finally, regression model 3 incorporates borrower sales and whether the loan is secured as two additional control variables for the subsample of syndicated loans with pricing information over the period 1998 to 2003.

The parameter estimates for logistic regression model 1 show several important stylized facts about traded syndicated loans. First, we find that syndicated loans that are larger, have longer maturities, and are underwritten by larger syndicates are more likely to be traded in the secondary market. These loans are less opaque and are probably more attractive to institutional investors who likely have an ongoing relationship with the agent bank. As we see below, these results are robust for all three regression specifications. Second, we find that syndicated loan purpose influences whether a loan is traded. Loans that are used for debt repayment, takeover activity, and leveraged buyouts are more likely to be traded, while general corporate purpose loans are less likely to be traded.

Third, the likelihood of a loan being traded is also influenced by borrower industrial classification and calendar time. Several industrial classifications are significant in determining whether a loan is traded. For example, loans made to borrowers in the mining sector are more likely to be traded. Calendar time has an impact on whether a loan is traded as well. These time effects probably capture increases in information about borrowers and technological changes (e.g., more sophisticated credit risk models such as KMV), which have greatly enhanced the size of the secondary market for syndicated loans by increasing the presence of institutional investors.

Table 5 reports binomial logistic regression estimates for three specifications. Model 1 incorporates loan, borrower, and lender attributes, as well as time effects. Model 2 and Model 3 expand the specification with supplementary information. As robustness checks, Model 2 includes pricing information (LEVERED and HIGHLY_LEVERED), while Model 3 incorporates both loan (SECURED) and borrower-level (LN_SALES) attributes.

Fourth, the lender-level variables that capture the number of syndicate members and how active the lender is in the syndicated loan market impact whether a loan is traded. We find that the more diverse the syndicate, as measured by the number of members, (N_SYN), the more likely the loan is to be traded. We also find that lender reputation affects loan trading. The relative size of the coefficients on the two variables identifying active bank lenders (BIG_BANK) and active nonbank lenders (BIG_NONBANK) shows that syndicated loans originated by large nonbank lenders are more likely to be traded than those originated by large banks. However, the greater the lending activity of the agent lender, whether it is a bank or nonbank, leads to a greater likelihood that the loan is traded in the secondary market, because the omitted categories for each of these two variables are the less active bank and nonbanks that are captured by the intercept term. 
Table 5:Logistic Regression Model Estimates

\begin{tabular}{|c|c|c|c|c|c|c|c|}
\hline \multirow{3}{*}{ INTERCEPT } & \multirow{2}{*}{\multicolumn{2}{|c|}{ Model 1}} & \multicolumn{3}{|c|}{ Model 2} & \multicolumn{2}{|c|}{ Model 3} \\
\hline & & & & & & Coeff. & Std. Err. \\
\hline & $-14.551 *$ & 0.4251 & $-20.888 *$ & 0.6823 & & $-24.5352 *$ & 1.0001 \\
\hline LN_FACILITY_AMT & $0.4796^{*}$ & 0.0212 & $0.7769 *$ & 0.0332 & & $0.6761 *$ & 0.0486 \\
\hline TICKER & $-0.1838 *$ & 0.0544 & -0.0399 & 0.0738 & & $-0.492 *$ & 0.0951 \\
\hline RATING & $0.8474 *$ & 0.0598 & $0.7709 *$ & 0.0813 & & $0.5827 *$ & 0.0977 \\
\hline MATURITY & $0.000256^{*}$ & 0.000087 & $0.000204 * *$ & 0.000084 & & $0.0291 *$ & 0.00206 \\
\hline REVOLVER_GT_1YR & 0.1093 & 0.0878 & $-0.2737 * *$ & 0.1301 & & $-0.7165^{*}$ & 0.1643 \\
\hline REVOLVER_LT_1YR & $-2.5823^{*}$ & 0.7184 & $-2.5238^{*}$ & 0.7301 & & $-2.1175 * *$ & 1.0328 \\
\hline TERM & $1.7163 *$ & 0.0828 & $1.0209 *$ & 0.1246 & & $0.5996^{*}$ & 0.1609 \\
\hline FACILITY_364 & $-2.1273 *$ & 0.1644 & $-1.4127 *$ & 0.2227 & & $-0.6346 * *$ & 0.318 \\
\hline PURPOSE_CORP & $-0.4393 *$ & 0.0743 & $-0.6052 *$ & 0.1116 & & -0.2311 & 0.1656 \\
\hline PURPOSE_DEBT & $0.1511 * *$ & 0.0659 & 0.1402 & 0.0908 & & -0.0366 & 0.1137 \\
\hline PURPOSE_TO & $1.059 *$ & 0.0674 & $0.8325^{*}$ & 0.0917 & & $0.505^{*}$ & 0.1157 \\
\hline PURPOSE_LBO/MBO & $1.8059 *$ & 0.0757 & $1.3467 *$ & 0.1048 & & $1.1342 *$ & 0.142 \\
\hline IND_2 & $1.1087 *$ & 0.1236 & $0.9365^{*}$ & 0.166 & & $0.6626^{*}$ & 0.2166 \\
\hline IND_3 & $1.0521 *$ & 0.1224 & $0.7769 *$ & 0.1644 & & $0.4546^{*}$ & 0.2112 \\
\hline IND_4 & $1.1583^{*}$ & 0.1217 & $1.1092 *$ & 0.1634 & & $0.7076^{*}$ & 0.2175 \\
\hline IND_5 & $1.1166^{*}$ & 0.133 & $0.8329 *$ & 0.1786 & & $0.5732 *$ & 0.2301 \\
\hline IND_6 & -0.2728 & 0.1513 & -0.0927 & 0.2017 & & 0.2732 & 0.275 \\
\hline IND_7 & $1.6728 * *$ & 0.1294 & $1.3758 *$ & 0.1725 & & $1.149 *$ & 0.2243 \\
\hline IND_8 & $1.4781 *$ & 0.1434 & $1.0601 *$ & 0.196 & & $0.7733 *$ & 0.2474 \\
\hline DUMMY_1998 & $0.7479 *$ & 0.0836 & -- & -- & & -- & -- \\
\hline DUMMY_1999 & $0.7316^{*}$ & 0.0849 & -0.1324 & 0.1024 & & $0.0699 *$ & 0.129 \\
\hline DUMMY_2000 & $0.876^{*}$ & 0.0864 & 0.0324 & 0.1039 & & $0.5523 *$ & 0.134 \\
\hline DUMMY_2001 & $0.8582 *$ & 0.0928 & 0.0317 & 0.1143 & & $0.5006^{*}$ & 0.1501 \\
\hline DUMMY_2002 & $0.8238^{*}$ & 0.0939 & -0.2177 & 0.1204 & & $0.4338 *$ & 0.1609 \\
\hline DUMMY_2003 & $0.7986^{*}$ & 0.0924 & -0.1331 & 0.182 & & $0.6^{*}$ & 0.2641 \\
\hline N_SYN & $0.0156^{*}$ & 0.00247 & $0.0238 *$ & 0.00364 & & $0.0108 * *$ & 0.00474 \\
\hline BIG_BANK & $0.3476^{*}$ & 0.0487 & 0.1079 & 0.0679 & & -0.0179 & 0.088 \\
\hline BIG_NONBANK & $0.7213^{*}$ & 0.0867 & $0.3586^{*}$ & 0.1114 & & 0.0735 & 0.1449 \\
\hline LEVERED & & & $2.1926^{*}$ & 0.1451 & & $1.5511 *$ & 0.2237 \\
\hline HIGHLY_LEVERED & & & $3.3531 *$ & 0.1431 & & $2.4658 *$ & 0.2259 \\
\hline LN_SALE & & & & & & $0.2522 *$ & 0.0391 \\
\hline SECURED & & & & & & $0.9205^{*}$ & 0.1688 \\
\hline $\mathrm{N}$ & 39,262 & & 18,799 & & & 8,598 & \\
\hline \# of Non-Traded Loans & 36,483 & & 17,097 & & & 7,283 & \\
\hline \# of Traded Loans & 2,779 & & 1,702 & & & 1,315 & \\
\hline Chi-Square (p-value) & .0001 & & .0001 & & & .0001 & \\
\hline-2 Log-likelihood & & & & & & & \\
\hline Intercept-only & $20,074.94$ & & $11,421.4$ & & & $7,356.1$ & \\
\hline -2 Log-likelihood & & & & & & & \\
\hline Full Model & $14,305.88$ & & $7,126.25$ & & & $4,159.3$ & \\
\hline McFadden $\mathrm{R}^{2}$ & & .71 & & & .63 & & .57 \\
\hline
\end{tabular}

The parameter estimates for logistic regression models 2 and 3 provide robustness checks for our basic set of results by examining two subsamples of syndicated loans. Specifically, logistic regression model 2 incorporates the impact of pricing on the likelihood of a loan being traded. However, pricing information is available on less than 50 percent of all the syndicated loans in the full sample. We find evidence that loan pricing plays an important role in determining which loans are traded. Highly levered loans are more likely to be traded than either levered or non-levered loans. This result agrees with popular press accounts, which argue that most of the recent growth in the secondary market trading of syndicated loans has occurred in the levered and highly levered segments. As such, levered and highly levered syndicated loans provide the highest yields for institutional investors. 
Logistic regression model 3 incorporates borrower sales (LN_SALES) and whether the loan is secured (SECURED) for a subsample of loans with pricing information. As expected, the coefficient on LN_SALES is positive. This suggests that the larger the size of the borrower (as proxied by sales), the less opaque the loan, and the more likely it is to be traded. Also, because a secured loan is less risky for secondary market participants, the positive coefficient on SECURED is what we expected in assessing the effect of a loan being collateralized on the likelihood of its being traded. It is interesting to note, however, that whether a loan is secured appears to capture the effect of lender reputation given that the variables BIG_BANK and BIG_NONBANK are no longer significant in logistic regression model 3 .

Finally, as a measure of goodness of fit, we also report McFadden $\mathrm{R}^{2}$ statistics calculated from the loglikelihood statistics, as well as chi-square tests for all three logistic regression models in Table 5. Based on these measures, the logistic regression models fit the data well.

\section{SUMMARY AND CONCLUSIONS}

This paper uses a unique trading data set for the period 1997 to 2003 to examine the determinants of which syndicated loans are most likely to be traded in the U.S. secondary market. We also present a statistical overview of the recent growth in the secondary market for syndicated loans. Our results document several important stylized facts about traded syndicated loans. For example, we find that syndicated loans that are larger, have longer maturities, and are underwritten by larger syndicates are more likely to be traded in the secondary market. Syndicated loans that are used for debt repayment, takeover activity, and leveraged buyouts are more likely to be traded, while general corporate purpose loans are less likely to be traded.

Also, syndicated loans that are originated by large nonbank lenders are more likely to be traded than those originated by large banks. Both lender reputation and capital levels most likely account for these results. Finally, we find that loan pricing plays a significant role in trading activity, with highly levered syndicated loans more likely to be traded than either levered or non-levered loans.

The dramatic increase in trading volume associated with the greater presence of non-bank investors has caused bid-ask spreads to narrow substantially in the secondary market for syndicated loans. Future research should examine changes in the bid-ask spreads for these loans and the factors that account for any differences in the sizes of the spreads among traded loans. In addition, it would be interesting to decompose the bid-ask spread into its transitory and adverse selection components and determine those factors that account for differences in the adverse selection component across traded syndicated loans.

\section{AUTHOR INFORMATION}

Peter J. Nigro is currently Professor and Sarkisian Chair in Financial Services at Bryant University in Smithfield, Rhode Island. Prior to joining Bryant, he served as a Senior Financial Economist in the Policy Analysis Division at the Office of the Comptroller of the Currency for over a decade. Dr. Nigro has worked extensively on important policy issues including subprime lending, credit scoring, small firm finance and bank capital. He wrote two of the first widely cited research papers on the impact of predatory laws. He has also provided expert witness reports on lending discrimination over the past year. Dr. Nigro's research interests include small business finance, credit risk modeling and bank compliance issues. Mr. Nigro received a bachelor's degree from the College of the Holy Cross, an M.A. in economics from the University of Southern California and a Ph.D. in economics from Boston College. He has published articles in journals such as the Journal of Money, Credit and Banking, Journal of Financial Intermediation, Journal of Financial Research, Journal of Financial Services Research, Journal of Small Business Finance, Managerial Finance, and Managerial and Decision Economics.

Jonathan D. Jones is a Senior Financial Economist in the Risk Modeling and Analysis Division at the Office of Thrift Supervision in Washington, D.C. His research interests include banking and financial institutions, financial markets, risk management, and econometrics and statistics. Prior to joining the Office of Thrift Supervision, he was a Senior Financial Economist in the Office of Economic Analysis at the Securities and Exchange Commission, a 
Financial Economist in the Office of Tax Analysis at the Treasury Department, and taught at Vassar College and the Catholic University of America. He received his Ph.D. in economics from the University of Colorado.

Murat Aydogdu is an Assistant Professor of Finance at Rhode Island College. His research interests include market microstructure, market efficiency, institutional investments, mutual funds and earnings forecasts. Before RIC, he was an Assistant Professor of Finance at Bryant University, and a Financial Economist at the Securities and Exchange Commission. He earned his PhD in Finance at the University of Iowa in 2000. He also holds an MBA degree from University of Massachusetts, Boston and a Computer Science degree from Hacettepe University in Ankara, Turkey.

\section{REFERENCES}

1. Assender, T., 2000 "Growth and Importance of Loan Ratings," in Tony Rhodes, Keith Clark and Mark Campbell, Syndicated Lending: Practice and Documentation, London UK Euromoney

2. Berlin, M. and Mester, L., 1992. "Debt Covenants and Renegotiation." Journal of Financial Intermediation 2 19-33.

3. Bhattacharya, S. and Chiesa, G., 1995. "Proprietary Information, Financial Intermediation, and Research Incentives." Journal of Financial Intermediation 4, 328-57.

4. Boot, A. and Thakor, A., 2000 "Can Relationship Banking Survive Competition?" Journal of Finance 54, 679-713.

5. Demsetz, R., 2000. "Bank Loan Sales: A New Look at the Motivations for Secondary Market Activity," Journal of Financial Research, 2000, 23 (2), 192-222.

6. Dennis, S. and Mullineaux, D., 2000. "Syndicated Lending," Journal of Financial Intermediation, Vol. 9, Issue 4, 404-426.

7. Diamond, D., 1991. "Monitoring and Reputation: The Choice Between Bank Loans and Privately-Placed Debt." Journal of Political Economy 99, 689-721.

8. Gadanecz, B., Dec. 2004. “The Syndicated Loan Market: Structure, Development and Implications,” BIS Quarterly Review.

9. Gonas J.S. Highfield M.J. and Mullineaux D.J., 2004. "When Are Commercial Loans Secured?," The Financial Review, February, vol. 39, no. 1, 79-99.

10. Greenbaum, S. and Thakor, A., 1987. "Bank Funding Modes: Securitization versus Deposits. Journal of Banking and Finance 11, 379-401.

11. Hubbard, R., K. Kuttner, and D. Palia, 2002, "Are There Bank Effects in Borrowers' Costs of funds? Evidence From a Matched Sample of Borrowers and Banks," Journal of Business 74, 559-81.

12. James, C., 1987. "Some Evidence on the Uniqueness of Bank Loans." Journal of Financial Economics 19, 217-35.

13. James, C., 1992. "Relationship Specific Assets and the Underpricing of Underwriter Services," Journal of Finance 47, 1865-85.

14. Jones, J., Lang, W., \& Nigro, P., 2005. "Agent Bank Behavior in Bank Loan Syndications," Journal of Financial Research 28 385-402.

15. Kihara, M., 2005. “Japan Loan Syndication and Loan Trading Association 2004 Review,” LSTA Loan Market Chronicle www.lsta.org/assets/files/Miscellaneous/Japan\%20Syndication\%20(5).pdf

16. Kulikowski, L., 2005. "Refis Fuel Record Year in Syndicated Lending," American Banker, Dec. 29, 2005.

17. Lee, S. and D. Mullineaux, 2004. "Monitoring, financial distress, and the structure of commercial lending syndicates," Financial Management (Financial Management Association), Autumn.

18. McAdams, M., 2005. "Beyond Convergence: Loan Market Evolution from 1990 to 2005. LSTA 2005.

19. Miller, M., 1998. "The Current Southeast Asia Financial Crisis." Pacific-Basin Finance Journal 6225-33.

20. Miller, S., 2003. "A Syndicated Loan Primer," in A Guide to the U.S. Loan Market, New York Standard and Poor's.

21. Okel, T., 2005. "The Syndicated Loan Market," forthcoming in $41^{\text {st }}$ Annual Bank Structure Conference.

22. Oliver Wyman, 1999. "Credit Process Redesign: Rethinking the Fundamentals," Oliver Wyman Report 9 (1).

23. Opdyke, J. 2005. "Bank-Loan Funds Provide Income and Relative Safety As Rates Threaten Bonds, Wall Street Journal, April 28, 2005, p.D2 
24. $\quad$ PaineWebber Equity Research, 1999. "The Biggest Secret of Wall Street.” May 1999.

25. Pennachi, G., 1988. "Loan Sales and the Cost of Bank Capital." Journal of Finance 43, 375-96.

26. Rajan, R. and Winton, A., 1992. "Insiders and Outsiders: The Choice between Informed and Arm's Length Debt." Journal of Finance 47, 1367-1400.

27. Simons, K., 1993. "Why do banks syndicate loans?" New England Economic Review (Federal Reserve Bank, Boston) 45-52.

28. S\&P, "The LSTA and Standard and Poor's Expand CUSIPS to Syndicated Loans," Press Release January 4, 2004.

29. Standard and Poor's, 2003. "Leveraged Lending 3QQ3 2003."

30. Standard and Poor's, 2000. "Global High Yield Bond and Bank Loan Ratings," available at http://www.standardandpoors.com/ratings/highyield/index.htm.

31. Taylor, A. A., Yang, R., 2003. The evolution of the corporate loan asset class. Loan Market Chronicle, 1921.

32. Weidner, David, 2000. "Syndicated Loans Gaining Leverage on Junk Bonds." American Banker, February 11, 2000.

33. Yago, G. and McCarthy D. 2004. "The U.S. Leveraged Loan Market: A Primer," Milken Institute Report, October.

34. Yi, Ha Chin and Mullineaux, D, 2004. "Are Bank Loan Ratings Relevant?,” Working Paper, University of Kentucky. 


\section{NOTES}

